\title{
Historical tradition and modern transformations of the algerian and persian housing environment
}

\begin{abstract}
Historically, the urban situation in the cities and towns of Persia and Algeria was highly specific. The hot dry climate contributed to a street network, which was protected from the sun as much as possible. Climate conditions determined the appearance of houses with flat roofs, small windows and white walls. The entire urban planning system had the main centre-the city (town) mosque. There were smaller mosques in the structure of residential areas, densely surrounded by houses. Just as under the influence of climate a certain type of residential building took shape, these same factors formed a characteristic type of mosque in the housing environment.

Globalist trends have affected even such a conservative sphere as Islamic religious architecture, as it gradually toned down striking regional features, which is explained by the typicality of modern building materials and structures and the international activity of various architectural and construction firms in different corners of the world. Over the centuries, two opposing images of the mosque have emerged - the pointedly magnificent Persian and the fortress-type of Maghreb (typical for Algeria) types. This paper reviews how specific climatic conditions and historical processes influenced the use of building materials, structures and decoration in the mosques of Persia's and Algeria's different regions.

Today we observe an erosion of regional features in the form and layout of modern mosques, which are analysed on the basis of the examples given. On the basis of a comparison of authentic mosques and erected by foreigners, it is proved how local features are gradually being eliminated and what this leads to.
\end{abstract}

Keywords: Persian houses and mosques, Algerian houses and mosques, natural conditions, building materials, internationalisation of architecture

\section{Introduction}

Islamic architecture as a whole has historically been characterised by great conservatism, due to the climatic conditions and local cultural and religious traditions.

Since ancient times, residential quarters with narrow curved streets have always been located so as to hear a call for prayer from the minaret. If the city was large and consisted of several quarters, in addition to the main city mosque, there were even smaller mosques. The traditional layout of the city (town) provided for the placement of the main city (town) mosque outside the residential area, in a square and not far from a bazaar. Many historical Muslim cities at first arose as medieval fortresses, which also shaped the specifics of the most compact urban development.

In residential development, the principle of social hierarchy was clearly adhered to. If we do not talk about the palaces of the nobles, we can mention a typical example of the development of the Kharijites' towns in Algeria (the valley of M'zab river), where the houses of religious persons and noble citizens were the closest to the main mosque standing on an elevation. Mosques were often built first, and residential buildings gradually formed around them. For example, in Ghardaia in Algeria, the city around the mosque on the mountain developed in a spiral, from top to bottom, and the plan of the city with houses resembles a huge spiral shell. The houses, in the courtyards of which date palms grow, are located on the slope of the mountain. Stepwise, and do not enclose the mosque, they are monotonous, two-storey, in the form of a cube, with the ground floor featuring an arched gallery, the first one is deaf, with small square windows like loopholes. Since Kharijit towns are in a desert climate, flat roofs are often used as open-air bedrooms.

The example of Kharijite towns is generally unique because the traditions of both residential and religious architecture have remained constant for centuries. The same conservatism in city planning and residential architecture remains in many cities of Iran and Algeria to this day. This creates problems associated with population growth, the advent of transport, and non-compliance with evacuation standards.

If we compare the climatic conditions of Iran and Algeria, then in Algeria they are more extreme-coastal territories are characterised by increased seismicity, and most of the country is in the Sahara desert, and this is where the nomadic population lives. Historically, the cities of Algeria arose as fortresses of the ruling military dynasties, and the outlines of the city walls were determined by the outlines of the coastline and terrain. Along the outer wall was provided a passage for the soldiers guarding the city, and several watch towers. Despite the long history of existence and the years of French colonisation,

* Yulia Ivashko Prof. D.Sc. PhD Eng. Arch., Kyiv National University of Construction and Architecture, ORCID: 0000-0003-4525-9182, e-mail: yulia-ivashko@ukr.net

** Dmytrenko Andrii, Associate Professor, National University 'Yuri Kondratyuk Poltava Polytechnic', ORCID: 0000-0003-4757-5218, e-mail: metr5555@ukr.net

*** Peng Chang, Kyiv National University of Construction and Architecture, ORCID: 0000-0001-7772-5200, e-mail: changpeng2277@ 
the layout of the historical part of many cities in Algeria retains its medieval fortress character, when the centre of urban life is the main mosque and the market square near it, from which narrow streets and dead-end passages extend, and into which the sections are oriented. As in most other Islamic countries, the privacy of citizens in Algeria is hidden from prying eyes; each old house has its own courtyard.

Streets in Kharijite towns are like narrow corridors with stairs and arches or wooden beams that support the walls of houses located on both sides of the street. The presence of stairs is common due to elevation.

Since the territory of Algeria, where the main historical cities are located, is located in a seismic zone with earthquakes up to 6-7.3 points on the Richter scale, this determined the optimal shape of both cube-shaped houses and the forms of mosques, which are similar. Local construction methods were also developed, the most exotic of which were in Kharijite towns. So, in Kharijites' houses and mosques it is cool even in summer, because they are built on the basis of the specific local building material 'timshent' —an instantly solidifying local cement mortar made from a mixture of local sand and stone. The peculiarity of laying 'timshent' was that it was stacked by hand, without any specific technique. The windows / loopholes in houses and mosques also corresponded to the desert climate, and so that the interiors did not appear dark, they were made white. In addition, historically they used local stone for walls and floors, clay bricks baked in the sun, burnt brick, palm wood, and the masonry bound by mortar.

On the one hand, the diversity of the historical heritage of the cities of Iran and Algeria, is an unconditional historical and cultural value, but at the same time it creates a number of problems, especially in small towns or in cities that have heritagelisted status.

One of the main problems is the placement of mosques in a cramped space, in a residential area of high density. To solve it, clearing the territories in front of the mosque by demolishing residential buildings is required. This is indeed very difficult to solve, given the conservatism and religiosity of the local population.

If one compares the architecture of mosques from different countries with residential buildings in these countries, one can come to interesting conclusions. Persian mosques, luxurious in their appearance, stand out from urban development. In contrast, Algerian mosques, which arose originally from fortresses, are more similar to residential buildings in towns, especially small district mosques, which are

III. 1. Huaisheng Si Mosque in Guangzhou. Watercolour by Chang Peng, 2020

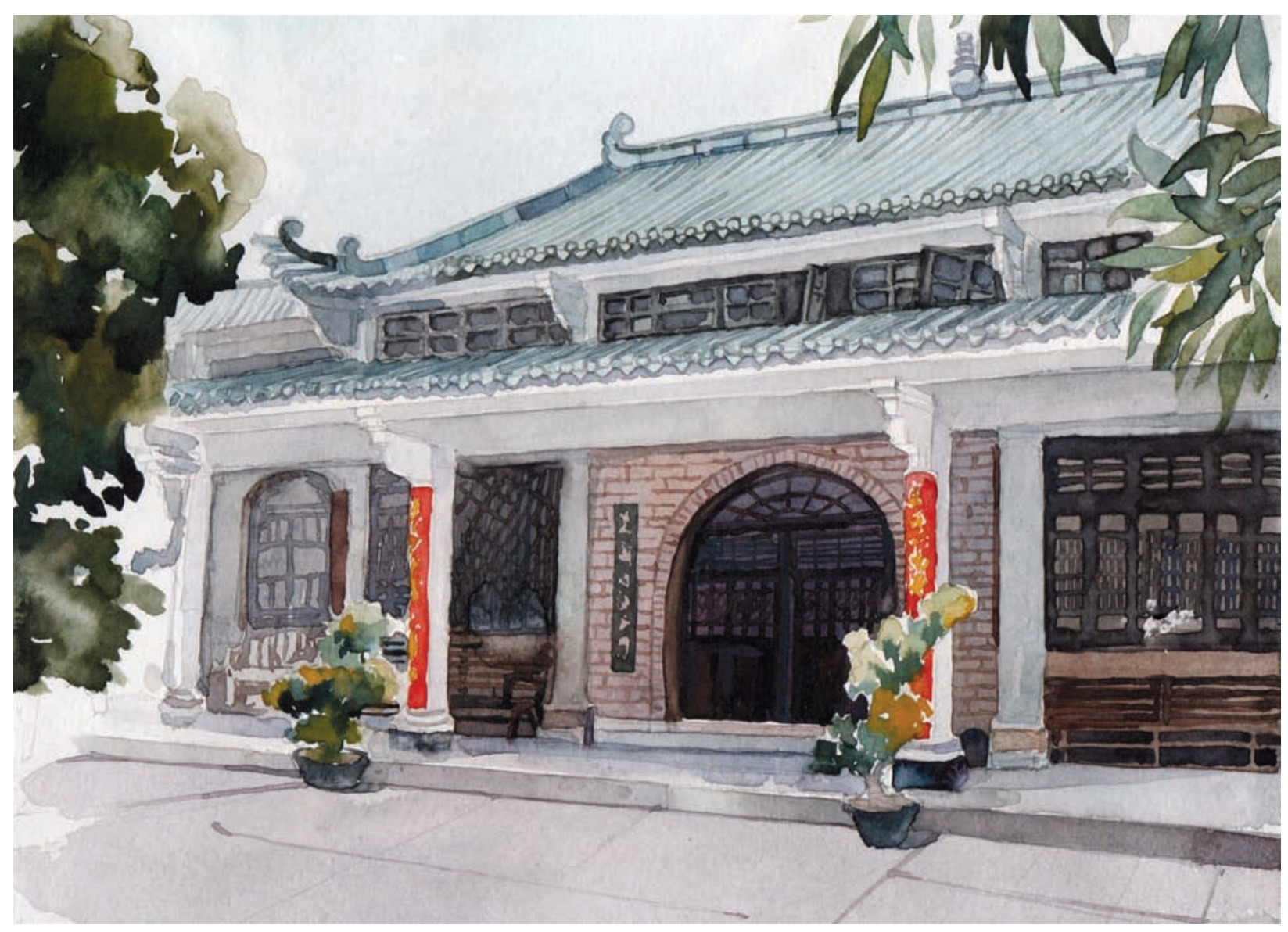


often difficult to distinguish from a house, except for a tall prismatic minaret.

Islamic religious architecture, even in the face of globalisation and the erosion of regional features, remains one of the most conservative branches of modern architecture. In particular, there is no decrease in believers in Islamic countries and, as a result, the conversion of religious buildings to other functions, as observed in Spain, England, and Germany. Instead, new mosques are being erected.

A mosque is a unique type of building which has invariably retained its multifunctional character for many centuries while playing a spiritual, educational, social and cultural role in society (Grube, Dickie, Grabar et al., 1984; Vayssettes, 2002; Zawiya, 2007). Against the background of the general processes of globalisation, it both preserves existing functions and increases their number.

Unlike a Christian temple, the mosque has far fewer canonical restrictions. Moreover, the mosque can use the architectural techniques of residential architecture of different countries and in general be outwardly similar to a residential building. One example of such an atypical mosque in the image of an apartment building of the Chinese nobility is described below.

The mosque is a type of highly adaptive building that is not as conservative in architectural design and layout as an Orthodox church, where each element is canonical and clearly defined. Such properties of the mosque as a place of group prayer (not a House of God, as a temple in Christianity) led to an extraordinary diversity of the architectural image of the mosque, which on the one hand depended on the specifics of natural and climatic conditions, and on the other-on local cultural traditions. When mosques were built in territories dominated by other religions, they could take on architectural forms characteristic of those territories, which is clearly evident from the example of the Huaisheng Si Mosque in Guangzhou in southern China, built, according to legend, by the uncle of the Prophet Muhammad in the 630s (III. 1).Over the centuries, the mosque has been rebuilt several times, in the early twentieth century authentic arbour structures have been replaced with concrete, and the flooring structures of the prayer hall are also modern. The subtropical warm and humid climate, coupled with strong local traditions, led to an atypical image of an Arab mosque that is indistinguishable from Chinese Taoist temples, combined with the distinctive appearance of a minaret stone tower. In addition to the building, the mosque area includes an open interior space with traditional Chinese landscaping techniques. The site also found space for a Chinese-style arbour, which is also not typical to the traditional layout of an Arab mosque.

Arguably, the Arabian hypostyle mosque, which subsequently transformed within each Islamic architectural school under the local climatic conditions and architectural and construction traditions, was the symbolic 'cradle' for all types of mosques. As a result, a growing number of regional peculiarities became sequentially superimposed on the canonical foundation: Arabic (Syrian-Egyptian), Maghreb, Persian, Indian and Ottoman schools were created in this way (Grube, Dickie, Grabar et al., 1984; Vayssettes, 2002; Zawiya, 2007). A significant role in this process was also played by the character of Islamic architecture in those countries, since their traditions were gradually transformed and incorporated into the architecture of mosques, as an element of the Islamic architecture of a particular school. For the Ottoman school, Byzantine Christian architecture became its influential architectural and construction base. It initiated the spread of lavishly decorated multi-cupola mosques with an emphasised size and height of a more extensive central dome and the order system; the principle of the pyramidal structure of the main body with a staged composition of the smaller domes around the central one (modelled after Hagia Sophia-Church of the Holy Wisdom-in Constantinople), the emergence of the sophisticated design with extensive walled galleries, smaller cupolas and a courtyard. For the Persian school, the architectural and construction base was magnificent pre-Islamic heritage with the use of luxurious decor and polychrome, the influence of which also spread to Central Asia and Iraq.

Change-resistant regional elements which transferred to Islamic religious and palace structures, were the Zoroastrian Sassanian chartaq, the Sassanian iwan and the Achaemenid palace apadana (Habib, 2007; Vayssettes, 2002; Zahedi, 2017; Zawiya, 2007). All of the above resulted in the pronounced predominance of the open courtyard over the built-up area and the formation of the Persian lavishly decorated iwan-type mosque. During the development of the mosque in Persia, its principal regional type gradually formed with a large open courtyard with galleries around it, with a modified dome body within the central part of the prayer hall, four iwans and two symmetrically located minarets on either side of the main entrance, with continuous decoration planes outside and in the interior and the transformation of the elements of the supporting structures to the decor element (Habib, 2007; Vayssettes, 2002).

The Maghreb school of architecture is the complete opposite of the Ottoman and Persian schools (Beguin, 1983; Bourouiba, 1982, p. 86, 100, 102, 106; Benyoucef, 1994; Brosselard, 1858; Golvin, 1960; Golvin, 1974). Its architectural and construction basis were the fortifications of the Berber military dynasties adapted to natural and climatic conditions and seismicity; it brought to the emphasized simplicity and geometry of mosque shapes, their functionality and the lack of decor; and, at the same time, local building materials and structures were used (Bourouiba, 1982, p. 86, 100, 102, 106; Bros- 
selard, 1858). A particular exception was the presence of noticeable influences from Al-Andalus, where the architecture was characterized by luxury, the presence of decorated interior spaces, which led to the gradual recession of Maghreb mosques from pure functionality and lack of decoration towards improving decoration and a decrease in scale (Ivashko, Rezga, 2018; Ivashko, Rezga, 2019; Rezga, 2019).

Despite the appreciable difference between all Islamic architectural schools, some processes were general in nature. However, changes in the image, layout, list of functions, structural systems, building materials and refined decoration, the mosque today, as at the beginning of the emergence of Islam, remains the main spiritual centre that attracts people and remains a symbol of unity of the community of believers.

Another feature of the development of a mosque as a place of prayer is that this process has always been closely connected with the politics of the ruling circles since rulers who professedd Islam contributed to the construction of mosques and their transformation into the central urban development landmark. And if in Persia the mosque gradually evolved towards a magnificently decorated large-scale complex, in front of which there were formal areas, then in Algeria, the location of mosques in the urban environment depended on the specific climatic conditions of northern Africa and the desert territories of the Sahara.

It was impractical to arrange large courtyards at mosques, and there were no vast formal areas in front of them be-

III. 2. Djama'a al-Kebir in Ardestan. Plan. Drawings by Yulia Ivashko

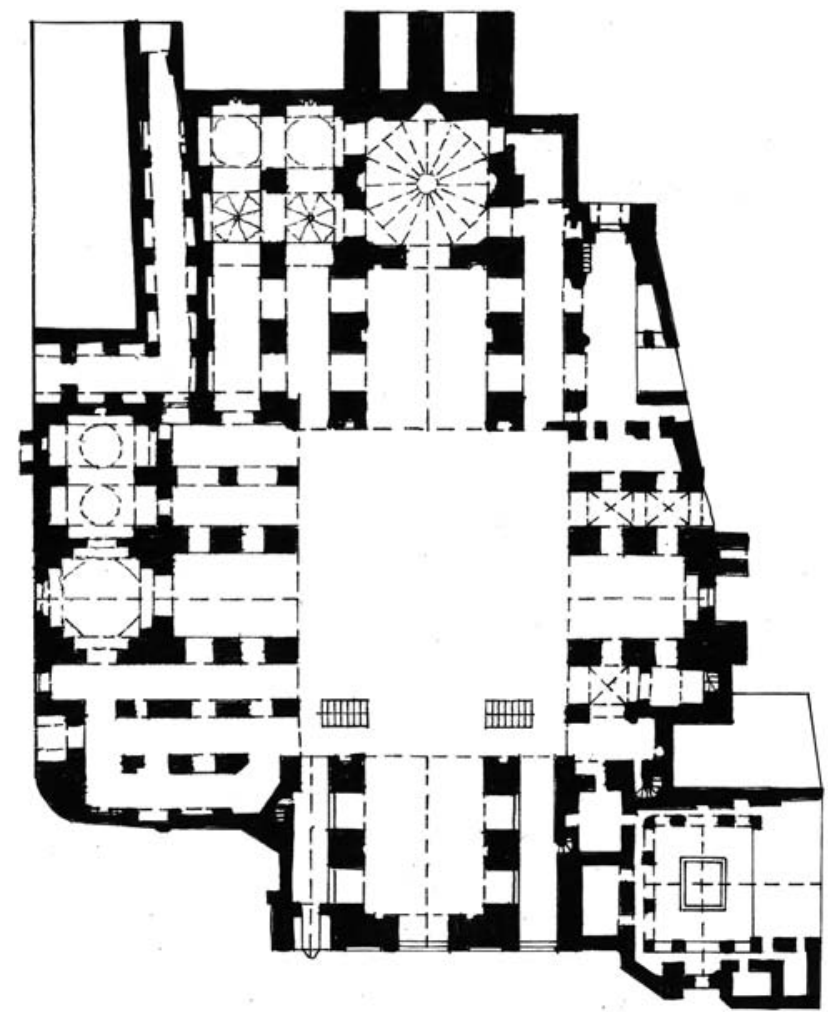

cause ancient Algerian cities were erected as military fortresses-kasbah-with the medieval defensive principle of planning (Bourouiba, 1982, p. 86, 100, 102, 106; Brosselard, 1858). Consequently, even with the assistance of local rulers in Islamic construction, Algerian mosques preserved a defensive character, and such a significant element of Islamic architecture as the minaret served not only religious (as in Persia), but also defensive functions (a signal tower) (Ivashko, Rezga, 2018; Ivashko, Rezga, 2019; Rezga, 2019).The tragic period of French colonisation led to the destruction or adaptive reuse of historical mosques of Algeria.

The process of building new mosques is the most active in those countries which, through purposeful colonial policies, have lost much of their own Islamic heritage. This happened in Algeria as a result of French colonisation. However, this has led to a simultaneous loss of continuity of national traditions in construction and architecture, and as a result new mosques have a more international character, especially when foreign citizens are sponsoring the construction and foreign firms design and build them. The internationalisation of building materials and technologies also contributes to the erosion of regional features, and as a result creates a universal image of the mosque that can be embodied either in Saudi Arabia, the United Arab Emirates or in Algeria and Tunisia. In this paper, the authors tried to draw attention to the need to preserve regional features in national construction, as they were most often formed as optimal for local natural and climatic conditions.

\section{Main part}

1. Building and decorative features of architectural structure

There were various influences on the planning structure and structural schemes of the mosques of Persia and Algeria. In Persia, the foundations of a Persian-type mosque were pre-Islamic palace buildings, residential architecture and houses with iwans, and Zoroastrian 'temples of fire' - chartaq. In Algeria, these were the defensive fortresses of Maghreb dynasties.

Subsequently, the modified domed square pavilion of the chartaq-type, built on a central axis, of the period of the Sassanid dynasty (it ruled from 224 to 651 $A D)$, starting from an early period, became an integral element of the Persian-type mosques and mausoleums, widespread not only in Persia but also in Central Asia, especially in Uzbekistan (the Samanids Mausoleum in Bukhara (the end of the ninth-tenth century), the mausoleum of Abdullah ibn Burayda, located in the Vekil Bazaar area of the Merv oasis and others).

In the early Middle Ages, the urban development of Persia was influenced not only by the canons of 


\section{axonometria}

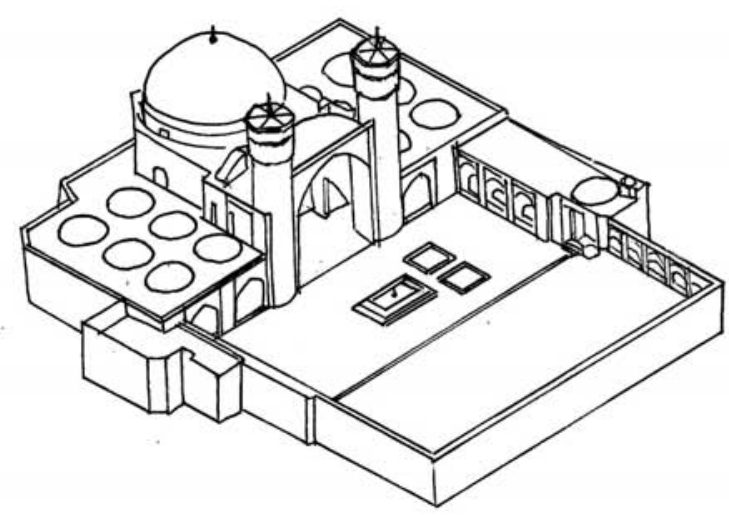

Djama'a al-Kebir in the city of Bouruzerd

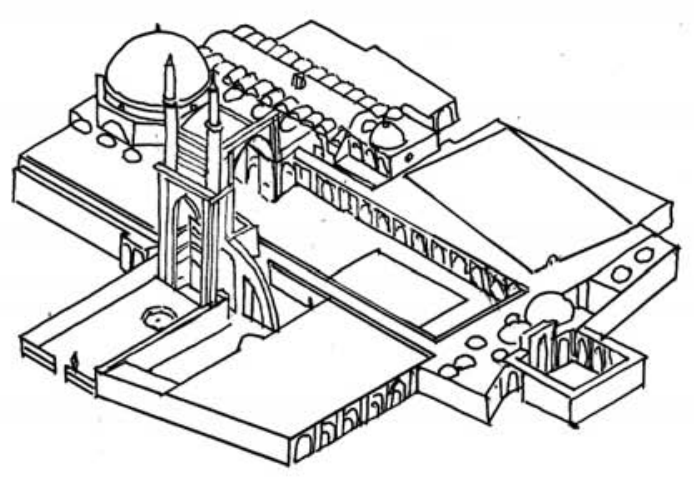

Djama'a al-Kebir in the city of Yazd

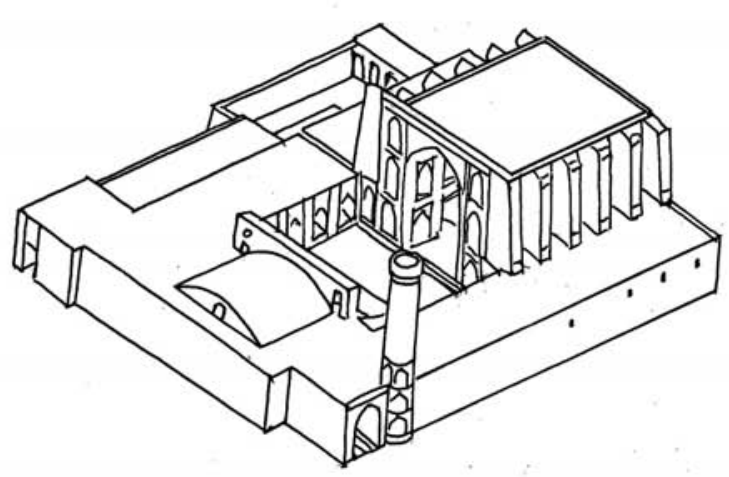

Djama'a al-Kebir in the city of Neiriz

III. 3. Types of compositions of historical Iranian mosques. Drawings by Yulia Ivashko
Islam but also by the specific climatic conditions in different parts of the country. The original regional features of the Persian Islamic school were determined by the active influence of both political events and the change of ruling dynasties, as well as constant ethnic migrations, multinational territories, as well as a unique pre-Islamic heritage, which led to the spread of multi-columned halls in mosques, the appearance of the modified chartaq and iwan. The asymmetry of planning demonstrates the complications of the volumetric-spatial composition and proves that some parts were added during different periods (III. 2).

Unlike the Maghreb type of domeless mosque, the Persian mosque demonstrates the presence of domes and half-domes of similar shapes in various objects, iwans with pishtaq portals and decorated minarets (III. 3) (Zahedi, 2017). In the early period of the construction of Persian mosques, the creation of the dome included the building of unloading arches, which brought together the octahedron to dioctahedron and cupola squinches. Wooden patterns were used for construction, which led to the similarity of the forms of covering.

While maintaining the Arabian scheme of the hypostyle mosque, the early Persian mosques were erected according to local building traditions, often using a system of parabolic brick arches on massive round brick columns with a wooden base as a connecting element between pillars and arches. Also, the structures of iwans on the transverse arches were borrowed from Sassanid residential architecture (Mosque of Moshir-i-Shiraz in Shiraz), however, they were subsequently modified by installing additional arches in the niches of the longitudinal walls to connect iwan with the parts added later.

At the high period of construction of mosques (between the sixteenth and eighteenth century), decorating or hiding structural elements became common; iwans were crowned with half-domes, which led to the discovery of squinches and pendentives on the facades. The building of mosques is still performed using burnt bricks; it has practically replaced the building from natural stone.

Throughout the evolution of the Persian architectural school, building methods were developed to withstand seismic vibrations: in the early and middle periods, by using alabaster mortar and ribs in a brick structure, the installation of longitudinal ties from round timber to counteract the subsidence of footing, and in the late period, reinforcement by the same connections with round timber against subsidence of walls and deformation of the dome and stalactite arches. At the turn of the middle and high periods, the types of vaults became varied; basket-handle arcs, flat vaults and rib vaults were added to them; but the number of cross vaults was reduced. The dominant type of dome on squinches 
was replaced by domes on reticulated and false sails, a developing type of a dome with a double shell and a dome in which the two shells have significantly different profiles; almost flat domes appeared. The late period was not affected by dramatic changes in design schemes, but by providing the structures with a luxu-

III. 4. Examples of historical Algerian mosques of the Maghreb type. Drawings by Yulia Ivashko

\section{examples of facades}

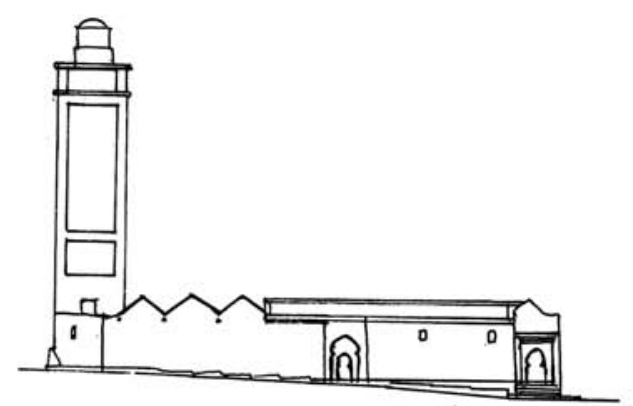

Djama'a al-Kebir in the city of Nedroma

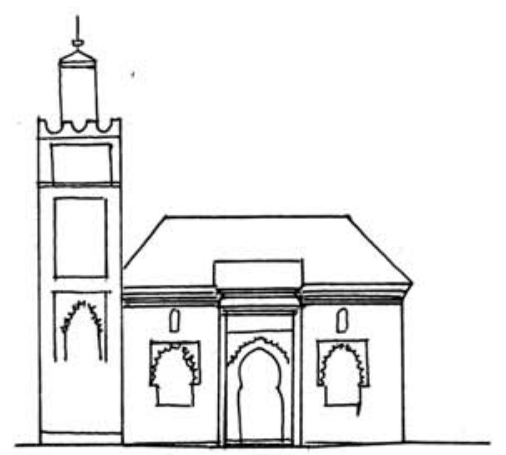

Mosque Sidi Bel Hassan in the city of Tlemsen

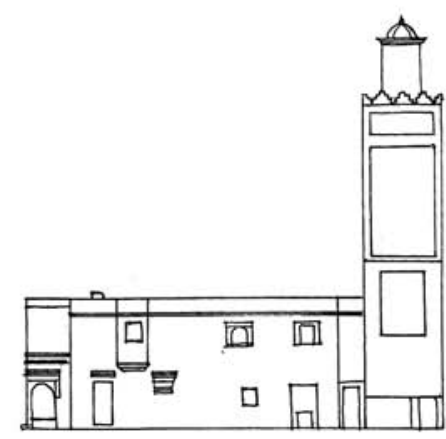

Mosque Sidi Mohammad Sherif in the city of Algeria rious look. In the third period the deviation from simple form and functionality to grandeur, scale and decoration were maximally manifested.

The three principal schemes of domes of the high period are as follows:

- the presence of an emphasised large massive central dome with a distinctive bulbous profile with a double shell, bearing a system of shieldshaped sails or a cascade of stalactites (principal type):

- a smaller, slender dome with a single shell, which rests on eight arches, four of which approach the corners and form a cloistered vault, with shieldshaped sails above the arches that support the drum ring;

- the dome system on the squinches, borrowed from the first and second periods and the supporting structure of the central dome based on crossed arches.

The principal schemes of iwans of the high period are reduced to the following:

- crowning of an iwan with upward bunches of shield-shaped or basket-net sails, which support the star-shaped vault of the half-dome, where the load is transferred from the dome to the flutes of the sail net and then to the angular supports (principal type),

- crowning of an iwan by a half-dome with glazed stalactites.

Another way was the evolution of building structures in Maghreb Islamic school (Rezga, 2019). Turning to the Islamic architectural heritage of Algeria, it is worth noting the simultaneous impact of climatic conditions and historical events on the formation of a specific image, design scheme and decoration of mosques. The influence of historical factors affected the multiplicity of impacts from the time when North Africa belonged to the colonies of the Roman Empire, and afterwards, given the regular change of the Arab, Persian, Berber, Ottoman dynasties that ruled Algeria between the seventh and the nineteenth century, as well as colonisation by the Spaniards, the Portuguese and the French. Besides, Algeria has a different ethnic composition, so each group has particular regional cultural and building traditions. In Algeria, the following zones are distinguished: the coastal territory (the so-called zone of permanent settlement); the middle zone (the seminomadic settlement zone); the southern zone (the nomadic population zone), it is the most of the country covered by the Sahara Desert.

The design schemes of Algeria's historical mosques are optimal for construction in conditions of the high seismicity of up to $6-7.3$ points on the Richter scale in the north, west and east of the country, especially the coastal areas where Islamic construction centres are located, such as Oran, Mascara, Algiers, Biskra, Constantine, Tlemcen, Béjaia, Touggourt, Mostaganem, Relizane, Chlef, Ain Defla, Bouira, Blida, Tizi Ouzou, 


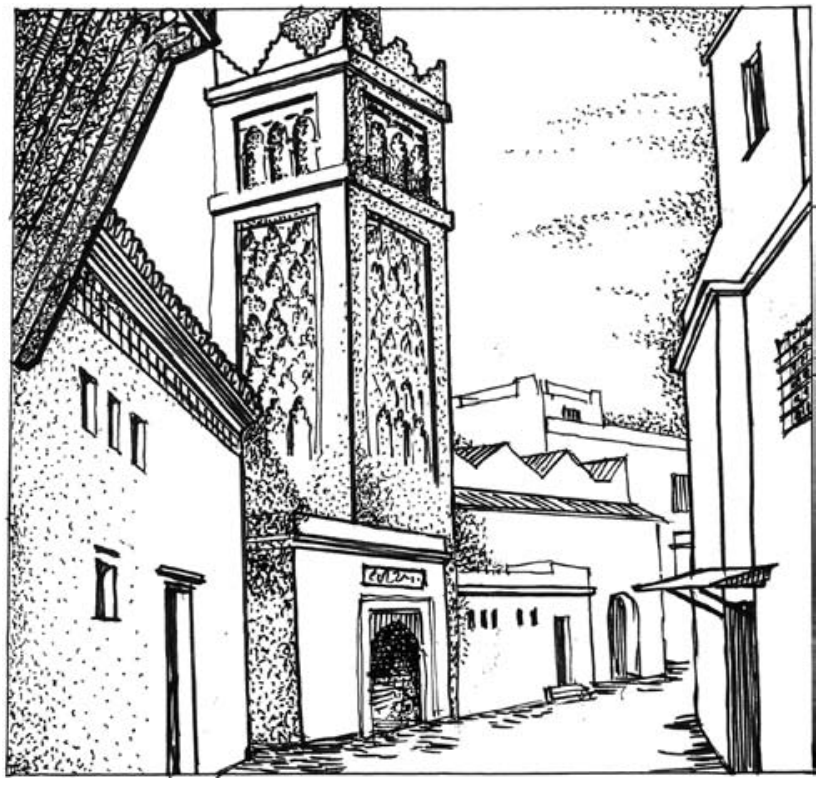

III. 5. Sidi Ramdan Mosque in Algeria. Drawings by Yulia Ivashko from the historical materials

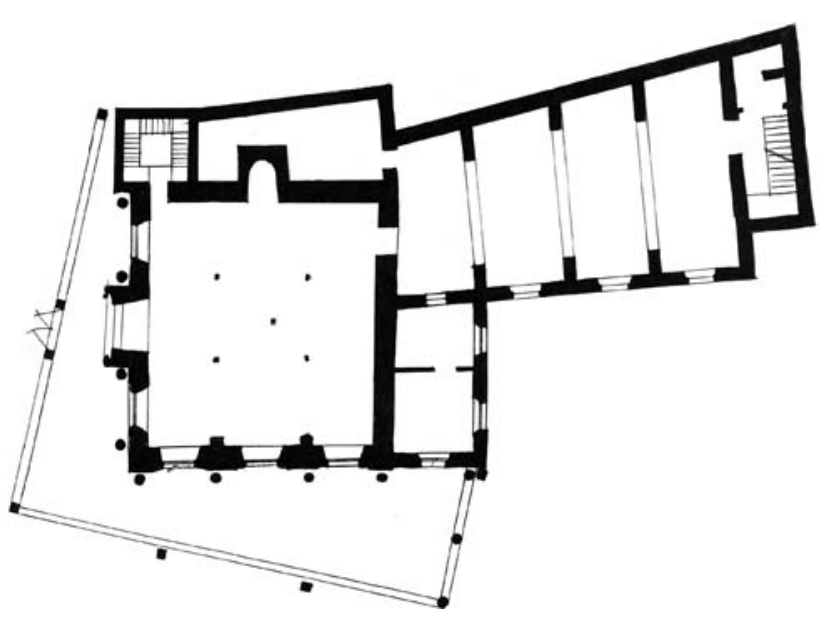

III. 6. Sidi Bellahsen Mosque in Tlemsen. Plan. Drawings by Yulia Ivashko

Annaba, Tebessa, Mila, Sukh Ahras, Batna, Ain Beida, Ain Témouchent and others (III. 4, 5, 6). The population, which suffered from earthquakes for centuries, gradually developed a type of mosques that worked optimally in seismic conditions, namely domeless mosques with a grid of columns separating the naves (III. 7), covered by separate gable roofs with wooden structures, with a two-tiered minaret, consisting of a combination of a large lower and a small upper prismatic mass, without a top in the form of a cone or dome, as it was the case with the minarets of the Persian or Ottoman schools. The absence of the dome was due to its inexpediency while building in the seismic zone. When a minaret of the Maghreb type was created, a precise ratio of the size in layout and height was accounted for, which was several times greater than the dimensions of the plan, the minarets were tall and narrow at the same time. The simplicity and a particular 'incompleteness

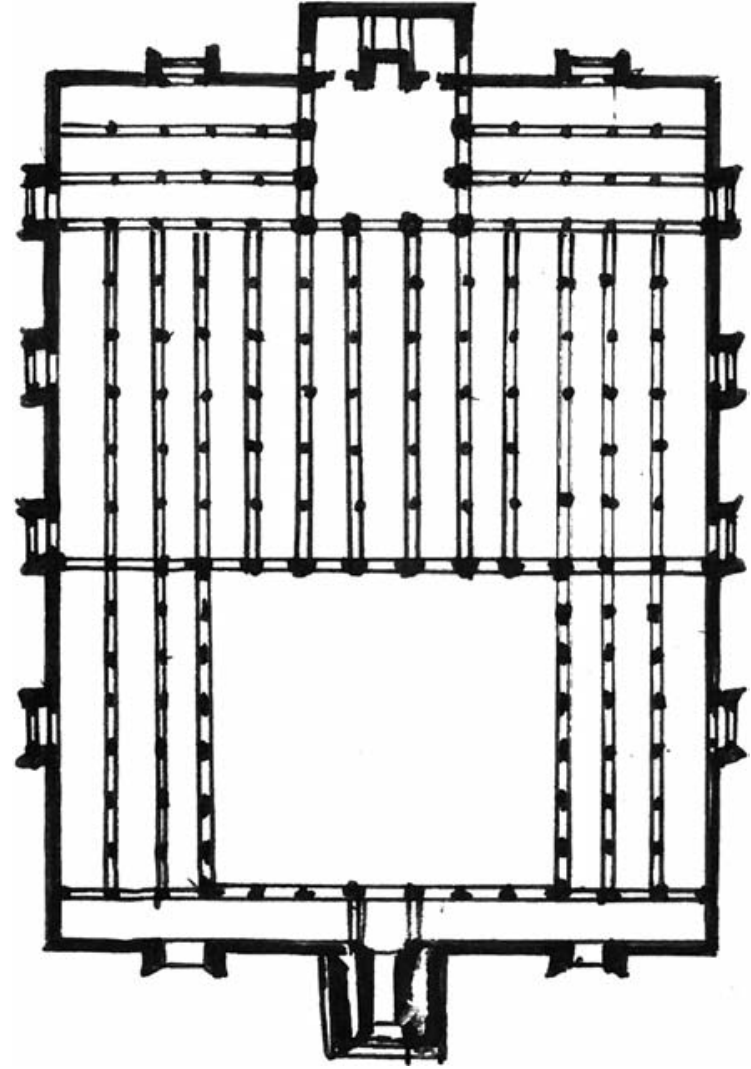

III. 7. EI Mansora Mosque. Plan. Drawings by Yulia Ivashko

of the crowning' of Maghreb minaret were caused not only by its direct origin from the defensive fortresses and signal towers but also because if such a narrow tall minaret had been provided with any crowning, in the case of seismic vibrations, it would have be destroyed as a result of the fourth type of seismic vibrations at the top, due to whip. There is another type of mosque adapted to seismic conditions that is authentic for Algeria, namely the domeless Kharijite mosque with a minaret in the form of a truncated pyramid with acute-angled crownings (Rezga, 2019). This type developed before the resettlement of the Kharijites in the M'zab valley, when they still inhabited the territory of Algeria, parts of the territories of Morocco, the Tlemcen Mountains, Sedrata, Taher in the west of the country, that is, in the seismic regions. If in the Maghreb type minaret the problem of resisting seismic vibrations was solved using a specific ratio of the plan area and height and the absence of crownings, then in the Kharijite-type minaret this problem was solved by expanding the minaret downwards (the centre of gravity is not far from the ground) and arranging acute-angled crownings above, which through its seismic vibrations with their amplitude dampen type-4 seismic vibrations (the so-called 'whip') in the upper part of the minaret.

The requirement to take into account the local seismic conditions required improving the design patterns of the pre-Islamic heritage in Algeria, in 
particular, the massive heavy ancient Roman vaults with walls up to $2 \mathrm{~m}$ thick were improved. As studied by Rezga Kouider, in ancient Roman arches, rubble and massive pieces of stone were used for masonry, while in the Islamic mosques between the reinforcement ribs that support and unload arches, brick and small stone pieces were used (Rezga, 2019).

Just as the Maghreb school was characterised by some regional structural schemes, it has the peculiarities of using local building materials. From this point of view, it is necessary to analyse the features of building materials of two authentic types of mosques-the Maghreb and Kharijite types.

The most stringent requirements were put forward during the construction of mosques by the Kharijite, where any decoration was seen as haram-forbidden. It was in the cities of the M'zab Valley with a hot desert climate and considerable differences in day and night temperatures that a particular construction technology emerged with an instantly solidifying local cement mortar made from a mixture of local sand and stone, the laying of which did not require formwork. The optimality of this local type of cement lies in its ability to maintain a comfortable indoor climate with small windows and painted walls, supports and floors in white.

The construction of Maghreb-type mosques included the use of ash and quarry stone for laying walls, floors and tiling, clay fired and adobe bricks, palm wood for the manufacture of beams and doors and lime mortar as a binder. Traditionally, for wooden floors in hypostyle mosques, wooden panel ceilings were used in the model of mosques of the Cordoba caliphate. As already noted, the dome was not inherent in the mosques of Algeria during Ottoman rule. However, when it was installed, it was placed over the mihrab and was small in size.

The dependence of the applied building materials and structures on a specific historical period is noted since foreign traditions were often borrowed. In the early period of the construction of mosques (the eighth century), some influences of Persian architecture were observable, unprocessed stone was used on lime mortar without decor; mosques had girders and arches. Later, between the tenth and thirteenth century, such Persian influences persisted and for the construction, they used rough stone on alabaster. In the minarets of the eleventh century, they used rubble stone, half-domes and arches, the walls were decorated. Since that time, attention was being paid not only to the design but also to the decor, the shape of arches became more varied, they become circular, lancet, multifoil, figured. In the thirteenth and fourteenth century, the carved stone, fired brick, tile, and stalactite vaults are used; there were examples of the use of masonry from a mixture of earth, lime and sand.

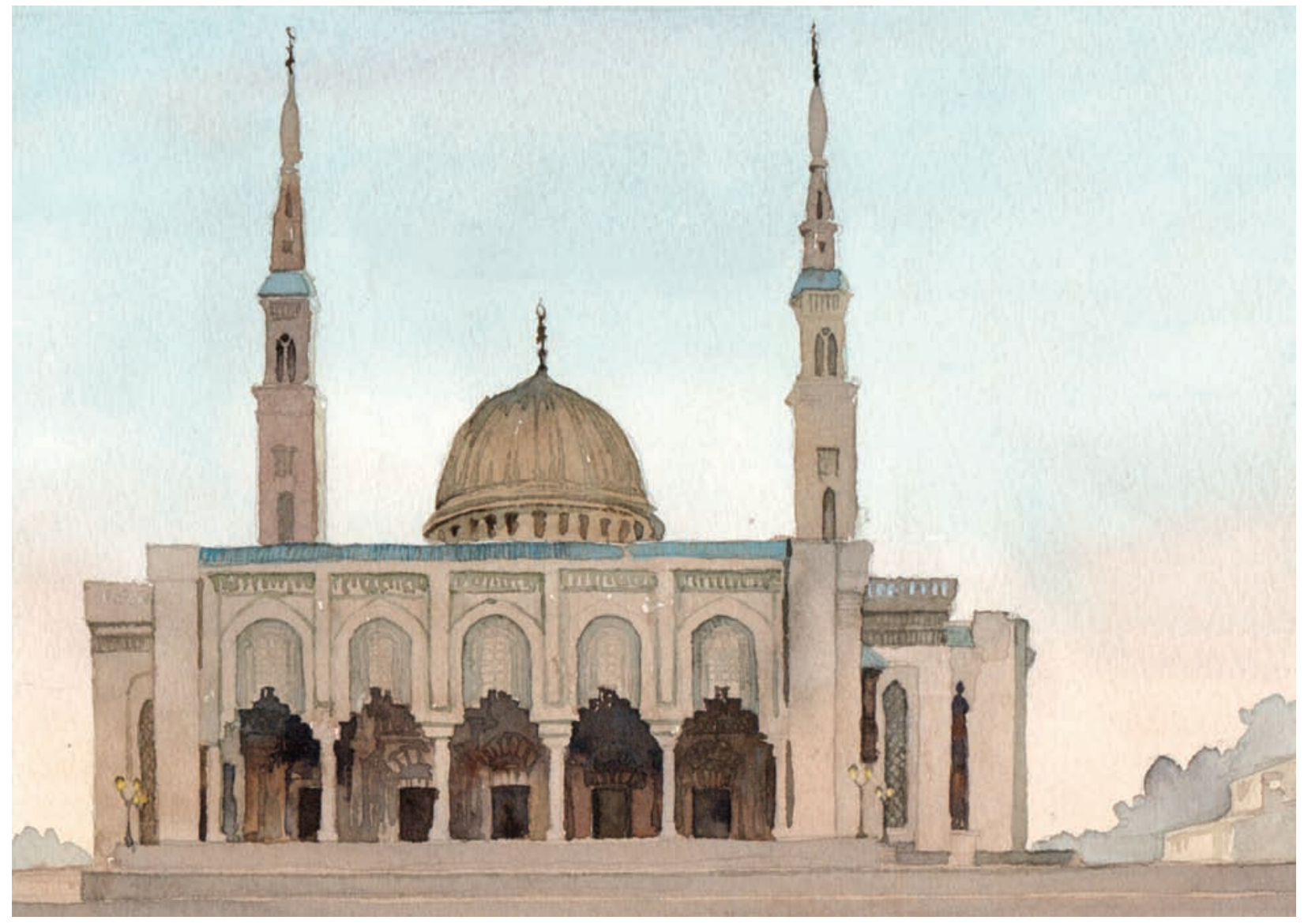


Although a dome was not a characteristic element of Maghreb mosques, during the reign of the Almoravid dynasty, a regional type of Maghreb construction of a dome was designed: made of brick 'on the edge', where the rows of masonry intersected with the formation of a star-like pattern, and the gaps were filled with plaster with carved decor.

\section{Current trends in modern Islamic architecture}

The main feature of historical mosques (for example, in Iran and Algeria) was that they were optimally adapted to the local natural and climatic conditions: thus, open courtyards with fountains were not used in Algeria with a desert climate in most of the territory. The absence of domed mosques during the reign of the Maghreb dynasties was explained not only by the origin of their forms from fortifications, but also primarily by local high seismic conditions. The outline of two-tier prismatic minarets is also not optimal for seismic conditions. Just how the misunderstanding of local conditions and the simple transfer of alien forms leads to a state of disrepair can be traced to the example of the Hassan Pasha Mosque in Oran, which was closed because of the building's emergency technical condition.

Islamic architecture today is one of the most active areas for the development of modern architecture and the application of construction technologies. Despite the preservation of the canonical image of the mosque and the presence of canonical components, the mosque is increasingly becoming an image of a modern multifunctional complex with a combination of spiritual, educational and cultural functions, as Islam must respond to modern world technology. The image of the mosque is becoming more modern, especially since the forms of Islamic construction do not contradict the forms of Neofunctionalism and Postmodernism with their simplicity and rectangularity. On this occasion L. Maciel-Sanchez highlighted several main stages in the development of modern Islamic architecture: the stage of gravitating towards Modernism and an abstractness of forms (the Mosque of Independence in Jakarta, 1961-1978, archi- tect Frederik Silaban, the Mosque of Bai-tul-Mukarram in Dhaka, 1960-1968, architect Abdulhussein Tariani), a stage of Postmodernism with a tendency to historise the image of the mosque (Mosque in Rome, 1984-1995, architect Paolo Portoghezi, Abdallah Saleh Mosque in Sana, 2001-2008).

The example of Algeria is exemplary in this regard, since there, after years of French occupation and destruction of Islamic heritage, new Islamic construction was intensified in line with the national decolonisation programme. In the third largest city of Constantine, on the initiative of the residents and with the support of the authorities, it was decided to build a new modern mosque named after Emir Abd al-Qadir-a multifunctional complex with a combination of a mosque and an educational institution-a university (III. 8) (Maciel, 2017). The author of the project was the Egyptian architect Ismail Hussein Mohammed, who was of the opinion that the mosque should not have a modern look and at the same time not be outdated. For example, the architect originally took the historic mosques of Morocco and the Sidi Boumedien mosque in Tlemcen as references, but the clients insisted on the associative image of the mosque spread from the Arab West from Spain to Libya, so the Grand Mosque of Cordoba was later used as the first example. Constantine's new mosque was built from 1972 to 1994 , although the university had been operating since 1984 .

The composition was based on a square hall with a dome to which a portico joins from the north, and from the south a closed two-storey building with a conference hall and university administration, on the first tier of the courtyard a mosque for women, and above them there are the study rooms of university students.

The innovation of planning and functional zoning was that the yard lost its transit function, expanded the list of functions and became two-tier, and the overall composition was determined by the princi-

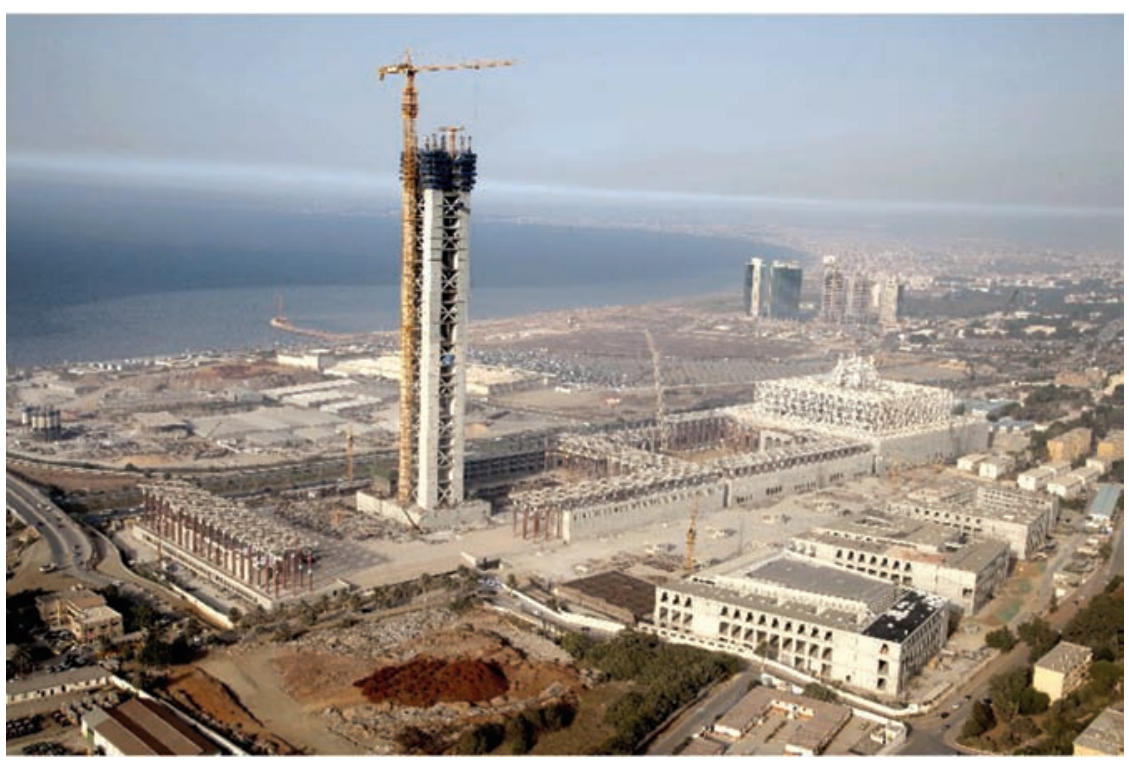

III. 9. The new Grand Mosque of Algeria (Djamaâ El Djazaïr) under construction. Source: https://www.kuk.de/ru/proekty/vysotnoe-stroitelstvo/detail/Projekte/ show/djamaa-el-djazair-grosse-moschee-von-algier.html (accessed:28.03.2020) 


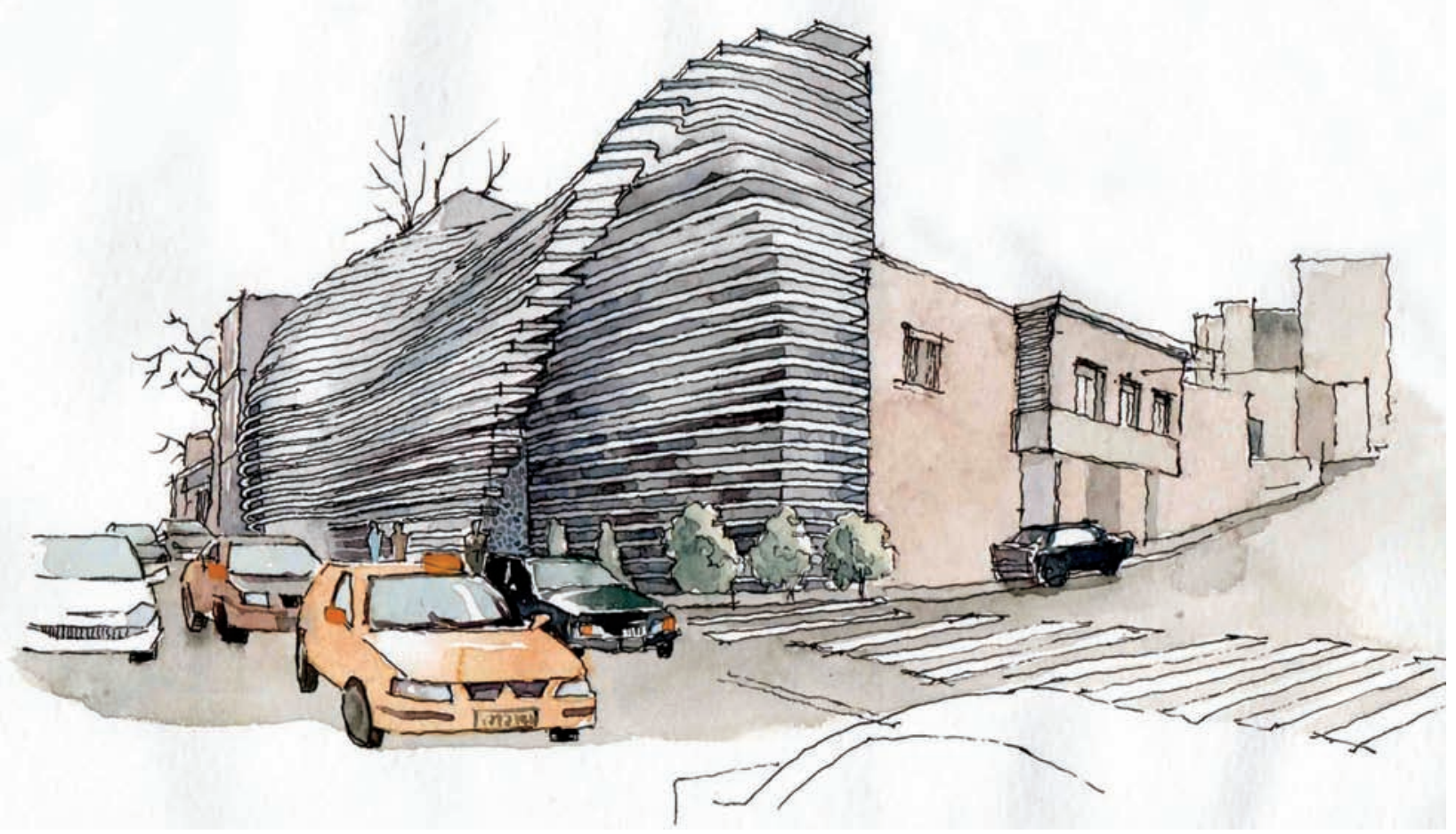

Fig. 10. General view of the Amir Al-Momenin Mosque in Tehran. Watercolour by Peng Chang, 2020

III. 11. Section and plan of the ground floor of the Amir Al-Momenin Mosque in Tehran. Source: http://tehne.com/event/koncepty/proekt-mecheti-amir-al-momenin-v-tegerane (accessed:28.03.2020)
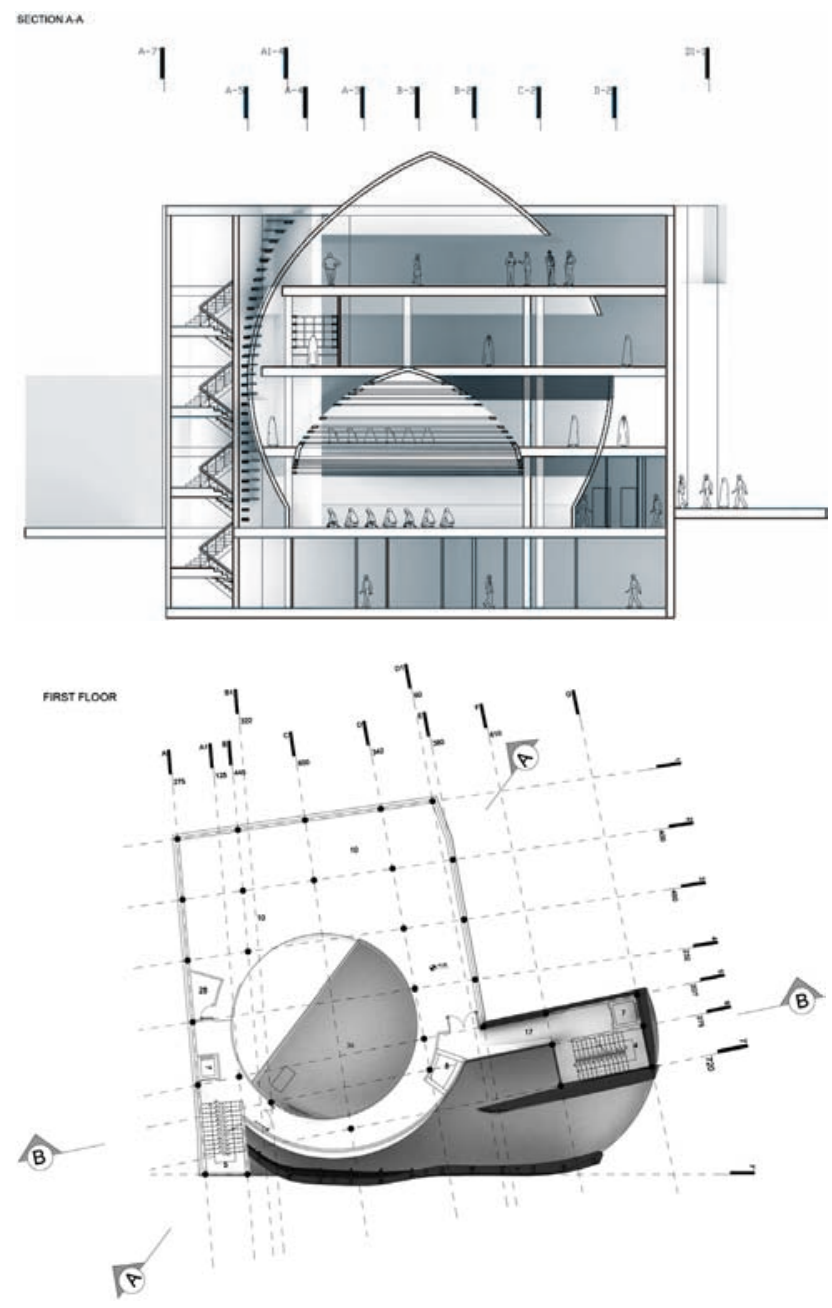

pal axis parallel to the wall of the qibla. The architect tried to embody some of the regional methods of designing mosques of the Maghreb type-the outlines of the capitals of the low columns resemble the early Maghreb mosques with Roman spolias (Great Mosque in Kairouan, Tunisia), the use of small decor sub-eaves of the facades under the roofs, and part of the windows with silos. Another departure from Maghreb's historical traditions was the arrangement of two main entrances-from the north through the developed esplanade and from the west opposite the wall of qibla, the presence of two paired minarets with a height of $107 \mathrm{~m}$ at the intersection of male and female prayer halls modelled on the funerary complex of Sultan al-Ashraf Qaytbay in Cairo, the dome in the centre of the hypostyle main hall, the juxtaposition of the illuminated and dark spaces of the central prayer hall, modelled on one of the later mosques in Cairo-the mosque-burial Mamluk style of ar-Rifai (1868-1885).

Innovation is also observed in the zoning of the hypostyle hall space where there are used the floorings of emphatically expanded bays and several naves by tall roofs that transmit a lot of light. Thus, despite the fact that the mosque's solution contains the Maghreb features, it also has echoes of Egyptian Islamic architecture of the Mamluk period, as well as echoes of elements more closely associated with Christian Gothic, though in some sources their primary origins are listed as the architectures are round rosettes, the system of cross-pointing drop arches of the domed space, the high part of minarets, similar to the high part of bell towers, which gives rise to certain analogies with the two-tower facades of Catholic cathedrals. Certain analogies to European Christian architecture are overloaded with decoration, which is gen- 
erally uncharacteristic of Islamic architecture in Morocco and Algeria. This similarity is also due to the direct influence of the colonial Catholic Cathedral of Our Lady of Africa in Algeria with the combination of features of European architectural Historicism of the nineteenth century and Islamic architecture.

The example of a new mosque in Constantine demonstrates an attempt to counteract the years of colonisation with its own modern 'Algerian' regional style of mosques, but as a result the architect embodied a certain 'mix' of traditions-not only Islamic in different countries, but also European and even ancient (in the nature of column capitals) (Maciel, 2017). However, he obviously would not have been able to accomplish this task otherwise, since the ancient mosques of the capital, the Nedroma or Tlemcen, were built by rulers of Berber dynasties common for Algeria and Morocco and their appearance is almost similar in the cities of these two countries. In addition, it was virtually impracticable for clients to embody the mosque of territories from the Cordoba Caliphate to Libya, since it led to a mix of different traditions and instead the idea of a 'modern Maghreb Islamic style' was actually expressed by the idea of a multi-vector of cultural and artistic mysteries, which is true, as proved by Rezga's studies (Khelifa, 2010; Rezga, 2019).

Let us examine the trends that are observed in modern Islamic construction. In Algeria's capital, under the design of Drees \& Sommer, in collaboration with Jurgen Engel and an engineering consulting firm from Germany and KREBS + KIEFER, the new Grand Mosque (Djamaâ El Djazair) for 120,000 worshippers with the world's tallest minaret $(265 \mathrm{~m})$ is under construction by the seaside (III. 9). It should be noted that KREBS + KIEFER is also specialised in high-rise construction. This mosque will become the third-largest in the Islamic world. If we analyse the design of the new mosque in comparison with the traditional mosque of the Maghreb type, it becomes clear that without the use of modern design schemes such large-scale construction in the area of high seismic activity would be impossible. The architecture of the mosque with a grid of concrete columns with complex fan-shaped endings of welded elements and a welded dome of metal structures is in essence a bold Postmodern rethinking of the historical traditions of Maghreb construction: a prismatic minaret with a combination of deaf walls and a glass top, erected in formwork, should give rise to analogies with the Maghreb minarets, but this is where the similarity ends. The building is impressive in its scale and originality, but elements such as large open courtyards with decorative basins, white walls of natural stone and a dome are not a traditional feature of Maghreb architecture, as well as the magnificent decoration of interior and exterior spaces.

The 2013 project of the Amir Al-Momenin Mosque in Tehran, designed by local architects Mahdi Kamboozia, Rasha Kiani, is an even more futuristic mosque (III. 10, 11).

\section{Conclusions}

The specifics of the urban environment of the historical towns and cities of Persia and Algeria depended on the climatic conditions, local traditions and very much on the religiosity of the population. Unlike the countries of Western Europe, which quickly passed the stage of the Middle Ages, many cities of Iran and Algeria can be said to be in a medieval state even today.

One distinct feature of the urban environment of many cities in these countries, especially small ones, is that, along with the emergence of new modern buildings and buildings of a new functional orientation, due to the conservatism of traditions and religious principles, the residential structure of residents often remains medieval. This applies to the separation of houses into male and female halves, maintaining a strictly private life away from prying eyes - the absence of windows in the walls facing the street, the presence of completely closed courtyards, etc. The example of the living environment of the Kharijite towns in Algeria provides a good illustration of this, as women there spend almost their entire lives in the walls of the house, almost without going outside, and on the streets and squares one can meet only men and boys. When going out, a woman can leave only one eye open. Although Kharijite towns attract tourists with their exotic nature, it is forbidden for strangers to enter some of them after sunset. Because of this, new trends in housing construction and in the construction of mosques are not widely perceived positively by the population. This is clearly seen in the appearance of Kharijite towns, which according to the canon reject all sorts of building decorations as contrary to the Qur'an. Their houses look the same as they did many centuries ago. At the same time, the benefits of civilisation in the form of computers, laptops and office equipment, as well as the modern situation in the interior, are gradually penetrating Kharijite residential buildings.

However, gradually even such conservative areas are penetrated by global architectural trends. The new mosques of Algeria are gradually losing their resemblance to fortresses and residential buildings and acquire a luxurious character.

The history of the Persian school mosques building structures development demonstrates the path of constant experiments and improvements of such elements as domes, iwans, vaults, which ultimately resulted in a high period in the transformation of structural elements to decor elements. The use of design schemes went in two ways-on the one hand, continuity with pre-Islamic construction was maintained between different periods, and on the other hand, there was an exploration of new design schemes. Some improvements were introduced by well-known architects, for example, the principal achievement of the Timurid period in constructions was the development of the dome scheme on the cross arches by the architect from Shiraz Kawama ad-Din, where the dome rested on four points of the massive arches with open inner edges and a concave surface of the offerings, where the angles between the arches were 
filled with shield-shaped sails of various configurations, which allowed changes in observing the interior due to the replacement of the squinch belts with arches and shield-shaped sails and decoration of niches with the stalactite the corners of adjacency of arches.

The history of Maghreb-school mosque structural system development primarily demonstrates a continuity of traditions from $t$ period to period when the structural schemes remained the same, and the changes concerned only particular elements and decor. The peculiarity of the mosques of the Maghreb and the Kharijite type is that they turned out to be more conservative to changes in design and image compared to the mosques of the Persian school, and such a characteristic element as the minaret remained unchanged in its image throughout all architectural periods.

Lev Maciel in his publication very reasonably used the term 'pan-Islamism', which, in our opinion, already accurately characterises those tendencies that have emerged in contemporary Islamic architecture and are determined by the blending of Islamic traditions of different countries (Maciel, 2017). This process has been intensified significantly with the appearance of new building materials, structures, engineering, since those natural factors that in the previous centuries clearly restricted the appearance of mosques (seismic conditions, desert climate, excessive sunlight, etc.) can now be offset by modern scientific and technological means: the creation of anti-seismic belts, shading structures, climate control, etc. Consideration should also be given to the significant changes that have taken place in society, which require the modernisation of the list of functions that are entrusted to a mosque and, accordingly, its modernisation as a specific type of building through changes in layout and image. On the one hand, this removes restrictions on certain compositional techniques and forms of elements, but on the other hand at the same time loses regional features of architecture that in the Islamic world have been optimally adapted to the natural and climatic conditions.

\section{REFERENCES}

[1] Beguin, François, 1983, Arabisances. Décor architectural et tracé urbain en Afrique du nord 1830 - 1950, Paris: Dunod.

[2] Bourouiba, Rachid, 1982, Abd Al Mu'min flambeau des Almohades, Alger: SNED.

[3] Benyoucef, Brahim, 1994, Introduction à I'histoire de l'architecture islamique. Alger: OPU.

[4] Brosselard, Charles, 1858, Les inscriptions arabes de Tlemcen, Revue africaine, 14, p. $86-94$

[5] Golvin, Lucien, 1960, La mosquee, ses origines, sa morfologie, ses divers fonctions. Son role dans la vie musulmane, Paris: Reliure inconnue.

[6] Golvin, Lucien, 1974, L'architecture religieuse des grands Abbasides, la mosquée d'Ibn Tulun, I'architecture des Aghlabides, In: Essai sur l'architecture religieuse musulmane, vol. 3, Paris, p. 192-198.

[7] Grube, Ernst J., Dickie James, Grabar Oleg et al., 1984, Architecture of the Islam World. Its History and Social Meanings, London: Thames \& Hudson.

[8] Habib, Allah Ayat Allahi, 2007, The History of the Iranian art, St. Petersburg: St. Petersburg Centre for Oriental Studies Publishers.

[9] Ivashko Yu., Rezga K., 2018, Study Methodology of the Architectural Periodization of Algerian Mosques and the Ritual Role of Elements (Mihrab, Minbar, Qibla, Bath for Ablution) in the Islamic Worship Service, Woda i zieleń w architekturze, Środowisko Mieszkaniowe (Housing environment), 22, p. 28-36.

[10] Ivashko Yu., Rezga K., 2019, Specific features and issues of preserving the historic cities of Algeria - centres of islamic construction, Wiadomości Konserwatorskie • Journal of Heritage Conservation, 58, p.143-147.

[11] Khelifa, Abderrahmane, 2010, Cirta Constantine la capitale celeste, Alger: Colorset.

[12] Maciel, Lev, 2017, Islamic Architecture and Contemporary Politics: Mosques in Constantine (Algeria) and Casablanca (Morocco), Actual Problems of Theory and History of Art: Collection of articles, 7. p. 609-618.

[13] Rezga, Kouider, 2019, National identity and external influences in the architecture of Algerian Mosques (XI century - 1830) (unpublished doctoral thesis, Kyiv National University of Construction and Architecture), Kyiv.

[14] Vayssettes, Eugène, 2002, Histoire de Constantine sous la domination Turque de 1517 - 1837, Paris: Bouchène.

[15] Zahedi, Shahab, 2017, Evolution of the architecture of mosques in Iran (8th - 18th centuries), (unpublished doctoral thesis, Kyiv National University of Construction and Architecture), Kyiv.

[16] Zawiya, A. A. Ali-zade, ed., 2007, Islamic Encyclopedic Dictionary, Moscow: Publishing House Ansar. 